\title{
ВИКОРИСТАННЯ ЦИФРОВИХ ОСВІТНІХ ТЕХНОЛОГІЙ У ПРОЦЕСІ МОРАЛЬНОГО ВИХОВАННЯ ДІТЕЙ $З$ ООП
}

\author{
Лілія Потапюк \\ кандидат педагогічних наук, доцент, \\ доцент кафедри соціогуманітарних технологій, \\ ЛНТУ «Луцький національний технічний університет» \\ м. Луцьк, Україна \\ ORCID ID 0000-0003-0830-8758 \\ potapiuk2020@gmail.com \\ Владислав Лінник \\ ЛНТУ «Луцький національний технічний університет» \\ м. Луцьк, Україна \\ ORCID ID 0000-0002-3043-2029 \\ linya77777@gmail.com
}

\begin{abstract}
Анотація. У статті окреслено проблеми використання цифрових технологій в методиці морального виховання дітей з ООП. Визначено шляхи розвитку активного залучення педагогів та батьків до ІК-технологій. Охарактеризовано позитивні моменти та недоліки їх впливу на формування особистості дітей.

Подано характеристику інклюзивного освітнього середовища як системи ціннісного ставлення до особистісного розвитку людей з особливими освітніми потребами, сукупності ресурсів (засобів, внутрішніх і зовнішніх умов) їх життєдіяльності в закладах освіти та спрямованість на реалізацію індивідуальних освітніх стратегій. Описано технології, які все ще знаходяться на стадії дослідження, але, ймовірно, будуть реалізовані протягом декількох років - технології управління комп’ютером подумки.

Проаналізовано нові інформаційні технології для осіб з обмеженими можливостями. Основну увагу звернено на можливості полегшеного управління комп'ютером з використання нових інформаційних технологій, а також комунікаційні можливості людей з обмеженими можливостями 3 усього світу за допомогою комп'ютерів. Класифіковано нові технології для людей з обмеженими можливостями, описано та вибрано програмні засоби та пристрої для полегшення використання комп'ютера. Охарактеризовано багатовимірність визначень та дефініцій у процесі характеристики базових складових освітнього середовища.
\end{abstract}

Ключові слова: діти 3 ООП; цифрові освітні технології; інтерактивна панель; електронне навчання.

Постановка проблеми в загальному вигляді. У навчальній літературі поняття «освітнє середовище» трактують як «сукупність умов, що впливає на формування й функціонування особистості в суспільстві, на іiі предметнопросторове оточення, здібності, потреби, інтереси і свідомість» (Безпалько, 2003). Багато дослідників відводять освітньому середовищу визначальне місце, оскільки саме воно об'єднує в собі і цілі, і зміст, й організацію освіти в 
Використання цифрових освітніх технологій у процесі морального виховання дітей з ООП

конкретному освітньому просторі; визначає вектор та склад здібностей і якостей людей, становлення яких відбувається під час освітнього процесу. Категорія «освітнє середовище» трактує розуміння освіти як сферу соціального буття, а середовище - як чинник освіти.

Так, вивчення феномену «освітне середовище» в контексті розвитку інклюзії дає підстави розглядати його як певну технологію інклюзивного навчання, оскільки будь-яка технологія спрямована на досягнення кінцевого результату - в нашому випадку, - це успішна соціалізація людей з особливими потребами. Отже, інклюзивне освітнє середовище має грунтуватися на загальних принципах інклюзії, враховуючи об'єктивні та суб'єктивні чинники ефективного розвитку в межах відкритої соціально-педагогічної системи, слідувати чіткій меті, реалізованій змістом інклюзивного навчання, впроваджувати інноваційну методику і засоби для організації освітнього процесу в умовах інклюзії (Гоцко, 2018).

На відміну від дорослих, діти з ООП, є емоційно нестійкими, тому дуже важливо створювати комфортне середовище для їхнього перебування. Вони ще не вміють добре контролювати свої почуття та власну поведінку, що може призвести до різних негативних наслідків як для самої дитини, так і для ії батьків. Розвиток цифрових освітніх технологій, безперечно, має величезний вплив на формування особистості дітей з ООП. Так, сучасні діти майже щоденно користуються телефонами, комп'ютерами та планшетами, тому дуже важливо, щоб інформація, яку вони звідти черпають, була безпечною та корисною i сприяла засвоєнню лише позитивних, високоморальних рис поведінки (Сушицька, 2020).

Сучасні педагоги вже досягли певного успіху, оскільки активно черпають знання про візуалізацію навчання дітей із порушеннями психофізичного розвитку в умовах українських закладів освіти. Проте, частіше за все, матеріальне забезпечення шкіл не дозволяє втілити усі задуми в реальність. Тому, цифрові технології є реальним виходом із важкої ситуації. Так, на допомогу дітям із порушеннями зору приходить крупний шрифт 18-20 та більших кеглів, аудіокасети, дискети. Для дітей із порушеннями слуху $є$ можливість дублювати звукову інформацію слуховою, використовувати додатки мови жестів.

Аналіз останніх досліджень $\mathbf{i}$ публікацій. Вивченням проблеми використання цифрових освітніх технологій у процесі морального виховання дітей з ООП займалися не так багато вчених. Питанням інформатизації інклюзивної освіти займалися: Л. Гаврілова, О. Пінчук, А. Коломієць. Зокрема, «Цифровий освітній простір: українсько-польський досвід». - Слов’янськ, 2021. 
Використання цифрових освітніх технологій у процесі морального виховання дітей з ООП

стратегію розвитку інклюзивної освіти в Україні окреслюють А. Колупаєва, Л. Міщик, Ж. Матюх; позитивні моменти та недоліки використання ІКТ - М. Котик, Ю. Носенко та інші.

Нині активно створюють все більше додатків та програми для управління комп'ютером за допомогою подиху (наприклад, програма Sensawaft), мигання повіками (програма «B-link»), рухів очного яблука (програма «Eye-trucker»), рухів голови (програма «Head Mouse Extreme»).

Таким чином, бачимо, що аналіз освітнього процесу дітей з обмеженими можливостями дає можливість визначити цілий ряд проблем у сфері надання освітніх послуг. I, насамперед, це проблема матеріального забезпечення закладів освіти. Тому необхідною сьогодні $є$ не лише розробка індивідуальної програми, а й впровадження комп'ютерної технології для оптимізації освітнього процесу. Проте, на жаль, досвід застосування комп'ютерної техніки в інклюзивному навчанні України мінімальний $\mathrm{i}$ потребує подальшого вивчення та вдосконалення.

Формулювання цілей статті (постановка завдання). Метою нашого дослідження є вивчення та аналіз проблеми використання цифрових освітніх технологій, виявлення недоліків системи інклюзивної освіти щодо залучення до IKT, забезпечення комп'ютерною технікою інклюзивних класів.

Результати дослідження. В українському законодавстві термін «діти 3 особливими освітніми потребами» використовується у вужчому розумінні інклюзивної освіти й охоплює дітей з порушеннями психофізичного розвитку та дітей з інвалідністю.

Дослідження психологів стверджують, що народження дитини з ООП докорінно змінює життєві перспективи сім'ї та чинить на неї (найбільшою мірою на матір дитини) тривалий психогенний вплив. Важкість деформуючого впливу подібного стресу на батьків залежить від характеру та ступеня порушень у розвитку дитини. Так, виявлена при обстеженні батьків специфіка особистісних порушень визначила систему заходів, спрямованих на їх корекцію. 3 метою проведення таких заходів розроблено методику психолого-педагогічної допомоги сім'ям, які виховують дітей з ООП.

У методиці виділяють два напрямки роботи: педагогічний (вплив засобами педагогіки) та психокорекційний, які представлені індивідуальною та груповою формами. Обидва напрямки активно користуються супроводом цифрових освітніх технологій і мають тоді значно більший вплив на дітей. Слід зазначити, що комп'ютерні технології - це технології навчання 3 використанням комп’ютера, його мультимедійних засобів та програмного забезпечення, які 
Використання цифрових освітніх технологій у процесі морального виховання дітей з ООП

розв'язують складні дидактичні завдання, вирішення яких без цього стають менш ефективними (Чигинцева, 2005).

Слід зазначити, що цифрова компетентність дозволяє людині бути успішною в сучасному інформаційному просторі, оперативно приймати рішення, керувати інформацією, а у дітей з особливостями психофізичного розвитку - знижує дефекти слуху, зору, мовної та моторно-рухової активності. Позитивно впливає використання нових інформаційних технологій i на мотивацію дітей під час опрацювання літературного тексту. Зокрема, у них підвищується інтерес до вивчення предмету.

Чимало дітей 3 особливостями психофізичного розвитку потребує особливих умов організації педагогічного процесу. Робота 3 батьками таких дітей має винятково важливе значення, оскільки їхнє розуміння природи труднощів і відповідна допомога в колі сім'ї сприятимуть подоланню труднощів у навчанні. Тому слід виокремити кілька порад батькам та педагогам для полегшення навчання на заняттях і вдома у роботі 3 дітьми 3 особливими освітніми потребами:

1. Робота з особливою дитиною повинна активізувати мовне наслідування, формувати елементи зв'язного мовлення, розвивати пам'ять і увагу - тут на допомогу приходять відео та аудіозаписи.

2. Малюйте предмети, які бачили, з якими грали протягом дня, називаючи при цьому дії, кольори, форми, величину, запахи, смак (мультимедійні дошки вам в допомогу).

3. Спостерігайте за дітьми сезонні явища, відмічайте, що змінилося (яскраво це можна зробити у вигляді презентації).

4. Казки служать для дітей першим уроком моральності. Це формує позитивні риси характеру і навички суспільної поведінки (казки можна не лише читати, а й записувати самим, або ж просто слухати).

5. Стимулюйте дружні стосунки (розмовляйте про друзів, родичів, записуйте приємні моменти на камеру).

Безумовно, педагоги та батьки складають основне оточення дитини, тому мають чималий вплив на неї. Для того, щоб покращити поведінку дитини 3 особливими освітніми потребами, можна зробити такі кроки:

1. Слід мотивувати дитину діяти в рамках норми.

2. Показувати позитивний приклад, самому дотримуючись правил.

3. Багато говоріть. Обговорюйте та визнавайте емоції малюка, саме так дитина зрозуміє, що ії люблять і підтримують. 
Використання цифрових освітніх технологій у процесі морального виховання дітей з ООП

4. Хваліть дитину кожного разу, коли вона виявляє позитивну й правильну моральну поведінку.

5. Для дитини слід стати прикладом для наслідування, аби вона активніше переймала правильні моделі поведінки (Чарова \& Савіна, 2017).

Набагато легше дитина це сприйме тоді, коли навчання відбуватиметься, ніби граючись - позитивний приклад транслюватиметься на відео, поради відображатимуться у яскравій презентації. Окрім того, у процесі виховання дітей з ООП слід активно використовувати мультфільми та кінострічки, які можуть стати цікавими для них. У роботі також можна використати аудіокниги, власностворенні відео, де діти зможуть побачити та почути самі себе (добре, коли педагоги володіють вміннями створювати подібне) (Генсерук, 2019).

В Україні курс інформаційних технологій успішно впроваджується в усі ланки освіти (дошкільну, середню, вищу). Використання інформаційних технологій на заняттях є одним із новітніх засобів розвитку особистості дитини, формування інформаційної культури і хорошим засобом виховання. Нині існує чимало цікавих технологічних засобів, але особливою популярністю у вихованні дітей з ООП користується інтерактивна панель «EdProTouch». Насамперед, це зручно, комфортно, сучасно та технологічно. Завдяки цій панелі можна зробити процес виховання набагато цікавішим та ефективнішим. Цей засіб чудово зарекомендував себе у найрозвинутіших країнах світу. Сучасний дизайн, новітні комплектуючі, гартоване скло (як захист від розбиття) є дуже важливими атрибутами у роботі з дітьми, бо ж, як відомо, діти люблять все яскраве та красиве.

Вчителі, які мають доступ до цієї панелі, володіють важливими інструментами для створення видовищних занять, де прямо зі сторінки інтерактивної книги можуть відкривати відео чи зображення, а учні отримують сучасне наповнення, можливість подивитись на будову тіла чи архітектуру в тривимірному вигляді.

Інтерактивна панель серед інших засобів цифрової інформації має такі переваги: немає тіні; замінює дошку; підтримує дотики; «антивандальна» (важко вплинути на нормальну роботу: витягнути кабель, розбити, тощо); невелика кількість приладів (чим менше приладів, тим менша ймовірність їх розсинхронізаціі); роздільна здатність (чим більша роздільна здатність, тим чіткіша картинка); дозволяє перегляд презентацій, відео, малюнків та запуск Windows-додатків; працює при денному світлі (Інтерактивна панель Ed Pro. Рішення для освіти, б. д.).

На жаль, фінансове забезпечення освіти в Україні не може дозволити впровадження таких панелей у всі заклади освіти, оскільки такі панелі $\epsilon$ 
Використання цифрових освітніх технологій у процесі морального виховання дітей з ООП

дороговартісними. Такими технологіями сьогодні володіють деякі приватні заклади освіти, хоч потребує подібного і сфера інклюзивної освіти.

Кілька останніх років польські вчені працюють над розробкою унікального додатку B-Link, що дає змогу паралізованій особі керувати комп’ютером рухом повік. Камера фіксує кожен їх рух, програма реєструє моргання користувача, яке має тривати не менше 1/4 секунди як натискання кнопки миші. Для введення символу з клавіатури особа з обмеженими можливостями повинна моргнути ще раз для переміщення рядками клавіатури, а потім ще раз, щоб можна було задіяти один із символів (Мосоров \& Панський, 2014).

Ще однією програмою, яка дає змогу людям з обмеженими можливостями користуватися комп'ютерами, $є$ Head Mouse Extreme (HeadMouse ${ }^{\circledR}$ Nano, б. д.). За iї допомогою курсором управляють рухами голови. На лобі користувача програми приклеєно маленьку крапку з тонкого матеріалу. Програма Head Mouse Extreme відслідковує цю крапку і відповідно до рухів голови переміщує курсор на екрані комп'ютера. Натискання миші реалізується затриманням курсору на деякий час в одному місці. Ще одним способом для натискання мишею $\epsilon$ підключення до програми Head Mouse Extreme синтезатора мови.

Доступним для вітчизняних педагогів $\epsilon$ навчання на порталах Mozaik, яке грунтується на використанні яскравих кольорів, що присутні у електронних підручниках 3 інтерактивними 3D сценами, навчальними відео та цікавими завданнями. Розробники додатку пропонують дітям та педагогам варіанти освітніх рішень для навчання в закладах освіти та вдома: відповідно «mozaBook» та «MozaWeb» (Електронне Навчання Mozaik, б. д.). Також пропонуємо звернути увагу педагогів, які працюють 3 дітьми з особливими освітніми потребами, на вказані нижче інноваційні інструменти, вміле володіння якими безпосередньо впливає на рівень засвоєння знань дітей та сформованості їхньої цифрової компетентності:

https://edpro.com.ua/education - комплексне рішення для освіти EdPro EducationKit;

http://powerpointbase.com/templates/ - шаблони презентацій PowerPoint;

http://powerpointbase.com/wordtemplates/ - шаблони Word для створення ефективного роздаткового матеріалу;

http://powerpointbase.com/diagrams/ - шаблони діаграм і графіків;

http://powerpointbase.com/certificates/ - шаблони сертифікатів, дипломів, грамот;

https://www.mozaweb.com/uk/mozabook - mozaBook Освітнє ПЗ для інтерактивної панелі та дошки; 
Використання цифрових освітніх технологій у процесі морального виховання дітей з ООП

https://www.ed-era.com/mon.html - поради вчителям, додаткові навчальні матеріали;

https://www.canva.com/ - Canva - дизайн для всіх і кожного;

http://www.newart.ru/htm/flash/risovalka_8.php - Animator - хмарний сервіс для створення анімованихgif;

http://paint.kards.qip.ru/compose/index/index.htm - PaintKards - хмарний сервіс для створення малюнків та анімаційних листівок;

https://play.google.com/store/apps/details?id=com.quvideo.xiaoying\&hl=uk відеоредакторVivaVideo-VideoEditor\&PhotoMovie.

\section{Висновки 3 дослідження і перспективи подальших розвідок у цьому} напрямі. Дослідивши проблему використання цифрових технологій в освіті дітей з ООП, було з'ясовано, що ІКТ в процесі навчання стає ефективним засобом розвитку дитини, сприяє формуванню у неї здатності до самостійності, самовдосконалення та самореалізації.

Нові інформаційні технології дозволяють спілкуватись з іншими людьми, підвищують мотивацію до дій, стимулюють більшу активність. Зосередження на потребах людей з обмеженими можливостями в плані доступу до комп'ютерів не тільки гарантує кожній людині право на знання, а й можливості ефективного спілкування з навколишнім світом. Особи, які через свою інвалідність не можуть повною мірою скористатися деякими формами діяльності, завдяки комп'ютерам можуть стати більш впевненими і незалежними.

Використання цифрових освітніх технологій на заняттях 3 дітьми з ООП сприяє виробленню у них комунікативних навичок, інноваційних умінь опрацювання інформації та значною мірою впливає на всебічний розвиток.

\section{СПИСОК ВИКОРИСТАНИХ ДЖЕРЕЛ}

1. Безпалько, О. В. (2003). Соичіальна педагогіка в схемах і таблииях. Київ : Київський центр навчальної літератури.

2. Генсерук, Г. Р. (2019). Цифрова компетентність як одна із професійно значущих компетентностей майбутніх учителів. Open educational e-environment of modern University, 6 , $7-16$.

3. Гоцко, Г. (2018). Особливості організації освітнього процесу в умовах реалізації основних засад інклюзивного навчання. Інклюзивне навчання в Новій украӥнській школі : матеріали Міжнародної науково-практичної конференції, м. Теребовля, 26-27.03.2018 р. Київ: Інтерсервіс, 28-30.

4. Електронне Навчання Mozaik. (б. д.). Взято з https://www.mozaweb.com/uk/

5. Інтерактивна панель Ed Рго. Рішення для освіти. (б. д.). Взято 3 https://edpro.com.ua/education

6. Мосоров, В. Я., \& Панський, Т. І. (2014). Нові інформаційні технології для осіб 3 обмеженими можливостями. Вісник Національного університету «Львівська політехніка», 803, 23-30. 
Використання цифрових освітніх технологій у процесі морального виховання дітей з ООП

7. Сушицька, К. Р. (2020). Всеукраӥнський фонд крок за кроком. Основні поняття : інклюзивна освіта, діти з особливими освітніми потребами, універсальний дизайн, розумне пристосування. Взято з http://www.ussf.kiev.ua/a/FAQ1.html.

8. Чарова, О. Б., \& Савина, Е. А. (2017). Особенности материнського отношения к ребёнку с интеллектуальным недоразвитием. Дефектология, 5, 34-39.

9. Чигинцева, Е. Г. (2005). Типологии семей в вопросе воспитания ребёнка с отклонением в развитии. Практическая психология и логопедия, 5 (6), 74-80.

10. HeadMouse ${ }^{\circledR}$ Nano. (б. д.). Взято 3 http://www.orin.com/access/headmouse/

\title{
USE OF DIGITAL EDUCATIONAL TECHNOLOGIES IN THE PROCESS OF MORAL EDUCATION OF CHILDREN WITH SEN
}

\author{
Liliia Potapiuk \\ Associate Professor of Socio-Humanitarian Technologies, \\ Lutsk National Technical University, \\ Lutsk, Ukraine \\ ORCID ID 0000-0003-0830-8758 \\ potapiuk2020@gmail.com \\ Vladyslav Linnik \\ Lutsk National Technical University \\ Lutsk, Ukraine \\ ORCID ID 0000-0002-3043-2029 \\ linya77777@gmail.com
}

Candidate of Pedagogical Sciences, Associate Professor,

\begin{abstract}
The article outlines the problems of using digital technologies in the methodology of moral education of children with SEN. The ways of development of active involvement of teachers and parents in IR technologies are determined. The positive moments and shortcomings of their influence on the formation of children's personality are characterized.

The characteristics of inclusive educational environment as a system of values to the personal development of people with special educational needs, the set of resources (means, internal and external conditions) of their lives in educational institutions and the focus on individual educational strategies. Describes technologies that are still in the research stage, but are likely to be implemented in a few years - mental computer control technologies.

New information technologies for people with disabilities are analyzed. The focus is on the possibilities of easier computer control with the use of new information technologies, as well as the communication capabilities of people with disabilities from around the world with the help of computers. New technologies for people with disabilities are classified, software and devices to facilitate the use of the computer are described and selected. The multidimensionality of definitions and definitions in the process of characterization of the basic components of the educational environment is characterized.
\end{abstract}

Key words: children with SEN; digital educational technologies; interactive panel; e-learning.

\section{REFERENCES}

1. Bezpalko, O. V. (2003). Social Pedagogy in Diagrams and Tables. Kyiv: Kyiv Center for Educational Literature.

Професіоналізм педагога: теоретичні й методичні аспекти. Методичні матеріали до проекту «Цифровий освітній простір: українсько-польський досвід». - Слов’янськ, 2021. 
Використання цифрових освітніх технологій у процесі морального виховання дітей з ООП

2. Henseruk, H. R. (2019). Digital Competence as one of the Professionally Significant Competencies of Future Teachers. Open Educational E-Environment of Modern University, 6, 7-16.

3. Hotsko, H. (2018). Features of the Organization of the Educational Process in the Implementation of the Basic Principles of Inclusive Education. Inclusive Education in the New Ukrainian School: materials of the International scientific-practical conference, Terebovlya, March 26-27, 2018, Kyiv: Interservice, 28-30.

4. E-Learning Mozaik. (n.d.). Retrieved from https://www.mozaweb.com/uk/

5. Ed Pro Interactive Panel. Solutions for education. (n.d.). Retrieved from https://edpro.com.ua/education

6. Sushytska, K. R. (2020). All-Ukrainian Foundation Step by Step. Basic concepts: inclusive education, children with special educational needs, universal design, intelligent adaptation. Retrieved from http://www.ussf.kiev.ua/a/FAQ1.html.

7. Mosorov, V. Ya., \& Panskyi, T. I. (2014). New information technologies for people with disabilities. Bulletin of the National University "Lviv Polytechnic", 803, 2-30.

8. Charova, O. B., \& Savyna, E. A. (2017). Features of the Mother's Attitude Towards a Child with Intellectual Underdevelopment. Defectology, 5, 34-39.

9. Chyhyntseva, E. H. (2005). Typologies of Families in the Issue of Raising a Child with a Developmental Disability. Practical psychology and speech therapy, 5 (6), 74-80.

10. HeadMouse ${ }^{\circledR}$ Nano. (n.d.). Retrieved from http://www.orin.com/access/headmouse/

Матеріали надійшли до редакції 10.10.2021 р. 